\title{
Technology Gap and Catching up in Economies Based on Natural Resources: The Case of Chile
}

\author{
Isabel Álvarez and Romilio Labra
}

\begin{abstract}
Many developing countries have defined successful catching-up strategies based on knowledge and capabilities upgrading. However, this is a path dependent country-specific process that may turn more complex in economies based on natural resources (NR). This paper adopts a knowledge-based economy approach to analyze the key dimensions of catching up applied to the Chilean experience. Results allow us to identify development drivers and to derive policy implications that can be generalized to other catching-up economies. The main contribution is to show how openness and some physical production factors become basic determinants of convergence for NR-based countries due to foreign technologies and knowledge absorption opportunities, while national innovation capabilities and the unequal income distribution are still serious weaknesses.
\end{abstract}

Index Terms - catching-up, Chile, development, innovation, technology gap.

\section{INTRODUCTION}

Chile has been successful in the implementation of policies and reforms during past decades with notable results in terms of levering economic standard when compared with other Latin America (LA) countries; however, the weakening of economic progress in the last decade urges the need for changes in the national development strategy. Some of the objectives are the increase of local capabilities that foster added value, the diversification of exports, and the correction of social inequalities [1]. The economic specialization of Chile, strongly based on natural resources (NR), adds serious challenges. As the evidence show, the NR exploitation may negatively affect economic growth due to several social, environmental, and economic factors that would explain the so-called "NR curse" [2]-[8].

The evolutionary vision of sustainable development is based on knowledge and technology as main drivers of growth [9], [10]. Accordingly, development strategies within the technology gap tradition confer special importance to both the access to foreign sources of knowledge as well as to local capabilities building process, along with an appropriate institutional context [11]. Under this view, economic growth is understood as a dynamic process implying several factors of different nature that evolve over time [12], [13], and

Manuscript received on November 10, 2013; January 17, 2014.

I. Alvarez is with the Facultad de Económicas \& Instituto Complutense de Estudios Internacionales, Universidad Complutense de Madrid, Spain (e-mail: isabel.alvarez@ccee.ucm.es).

R. Labra is with the Instituto Complutense de Estudios Internacionales, Universidad Complutense de Madrid, Spain and Institute of Agricultural Research, Chile (e-mail: romilio.labra@estudiante.uam.es). precisely this combination would become essential to understand a country trajectory and the reasons of growth.

Under this approach, primary assets (capital, labor, and NR) and exogenous technology are relevant in early stages of development, but to build on innovation capabilities is determinant for countries in order to advance in a perdurable progress path [14]-[17]. This aspect could explain part of the Chilean decline during the 2000s, and it would justify how different efforts to reach higher economic standard are still pending. Benchmarking and comparison with other economies based on a similar productive structure are good tools to identify weaknesses and opportunities that would support the definition of policies. This paper tries to identify the current frontier and the possibilities for catching up. For doing this, we first drive a metafrontier analysis and then an analysis of convergence. The analytical results provide knowledge about the gap determinants as well as general implications for countries dominated by NR industries.

The results suggest that countries specialized in NR should intensify openness and FDI for catching-up, to increase capital investments, and to build innovation capabilities, along with continuing with the exploitation of their NR as development basis. The opportunities for Chile derived from the resource management improvement are scarce because its technical efficiency is close to the frontier. Despite Chile's economic progress and convergence with the leaders, a wide gap of technological capability still remains and this is a serious obstacle for achieving and maintaining a better economic standard. Our findings also confirm that growth in Chile has been based more on traditional production factors and exogenous technologies, in line with the reforms and policies implemented since the seventies, while more efforts should be made to definitely take advantage of the opportunities provided by a Knowledge-based economy.

The rest of the paper is organized as follows: Section II presents a short revision of the main arguments found in the literature; Section III provides a brief description of economic structure, performance and trajectory of Chile; Section IV presents the methodology; Section V includes the most relevant results. Finally, Section VI presents the main conclusions and some policy implications.

\section{LITERATURE BACKGROUND}

A wide body of literature shows how countries can face development challenges by exploiting their endowments and increasing productivity. The traditional growth theory emphasizes the transition towards the steady state, being capital, labor, and crucially productivity the basic components of the cumulative process that guarantees 
economic progress. Under this lens, countries may converge taking advantage of the leaders' technology, while the international diffusion of technology is seen as the main driving process. However, it is well known that growth path is country-specific and while some economies actually converge, other fall behind. This can be explained by asymmetric access to knowledge and innovation determinants, being possible to characterize them as endogenous, cumulative, and complementary sources of growth [9]-[18], [11]-[21].

In the neo-Schumpeterian and evolutionary tradition, the explanation of growth differences across countries are built over a complex and dynamic vision of development that pays more attention to the role of technology and knowledge [9], [10]. This perspective is at the core of the knowledge-based economy framework and goes beyond the traditional productivity approach, claiming the crucial role of intangible assets as drivers of wealth creation [22], [23]. In this line, the results of convergence studies coincide to show that although countries can follow different development trajectories, they also share similar patterns resulting in clubs or groups of convergence, defined on the basis of their innovative ability and absorptive capacity [9], [17].

A crucial idea in this sense is that the international diffusion of technologies is not an automatic and effortlessly process. On the contrary, countries require domestic capabilities to select, imitate, adopt, and adapt foreign technologies and to create new ones, where the human capital and the institutional framework play a determinant role in this process [9], [10]. Even more, the adjustments needed to absorb new technologies can impose heavy costs on individual and society [24]. The opportunities to advance using knowledge from abroad also depend on the technology gap, because a closer proximity to leaders reduces the potential options for catching up. Authors such as Porter [15], Verspagen [9], Nelson [10], Castellacci [17], and Ville and Wicken [25], point out that in early stages of convergence, where countries face a wider technology gap, imitation is a main channel for economic development, while innovation become the most important driver for those in more advanced stages.

Moreover, the technology gap is not static but it is in constant change due to the combined actions of followers and their decision to catch up on the one hand, and the decision of leaders to innovate permanently on the other, which explains the differences in growth rates between the two groups of countries. The literature underlines that developed economies can growth to a higher speed because they are able to create and to accumulate knowledge faster than others thanks to their better institutions and well-instructed human capital [16], [10]. In addition, international protection of intellectual property, along with other regulatory mechanisms, act as barriers for international technology flows and knowledge spillovers, thus highlighting the relevance of internal capabilities. In this regard, Verspagen [9] argues that total convergence is not reached by means of catching up alone, but the backward country has to increase the domestic research efforts up to a level comparable with advanced economies, which support their progress on innovation.
The exploitation of comparative advantages without appropriate investments in knowledge capacities can make development problems persistent if countries do not move toward more innovative bases of competitive advantages [15], [9]. Additionally, countries with low efforts in education, institutions, $R \& D$, and innovation can be trapped in a slow growth path and also can fail in the transition trap from middle income to high income economy due to rising costs and competitiveness decline [26].

This adverse situation can be faced by countries through the acquisition of capabilities that permit the development of an appropriate national industrial strategy and the implementation of the most effective measures. In fact, countries that have jump the barrier of middle-income becoming high-income economies enjoy a more diversified, sophisticated, and non-standard export basket and by the time higher opportunities for structural transformations [27]. Thus, the key aspect to avoid this trap and to converge with leading economies is related to both institutional reforms and innovations capabilities that lead a continuous updating of technologies and diversified exports of higher added value contents, maintaining high growth rates in the long term.

Likewise, evidence of middle-income trap is found in economies based on natural resources (NR) due to the fact that these endowments tend to adversely affect growth because several reasons such as the easy generation of high incomes, the low growth potential of a fixed production factor, the negative effect of currency appreciation over manufacturing exports (also called Dutch disease), the generation of a wrong feeling of economic security that discourages investments in other assets [5], high levels of corruption and the reduction of the institutional quality [2], an inadequate distribution of human capital among industries [28], the negative effects in innovation systems [20], and the environmental damage [29], [30]. However, the literature on NR also suggests that countries could face sustainable growth if they foster human capital, strengthen their institutions and invest in knowledge and technology [28], [31], [32].

\section{THE CHILEAN TRAJECTORY}

Located on the southwestern edge of South America and with around 17 million people [33], Chile has shown positive signs of economic progress in the global context due to the policies and structural reforms applied along the last four decades, oriented to increase the economic activity, transforming exports and investment into the main engines of growth [34]. The economic trajectory of Chile shows that Per capita GDP increased by more than one and a half time since 1980 (Fig. 1), reaching the highest growth within LA and indeed, in the last World Bank (WB) classification Chile is found among the high-income countries [35]. The rate of growth in the period is higher than the Latin America average, as show the following Fig. 1.

In the 1970s, Chile began its international trade orientation and opening strategy through a reduction of protection at the multilateral level followed by bilateral free-trade agreements, which also attracted FDI flows [36], [37], [1]. Macroeconomic reforms followed with different 
governments, driven by stabilization and opening, and also some microeconomic policies were implemented to increase efficiency and productivity, while constitutional changes tried to strengthen the democratic governance of the country [38].

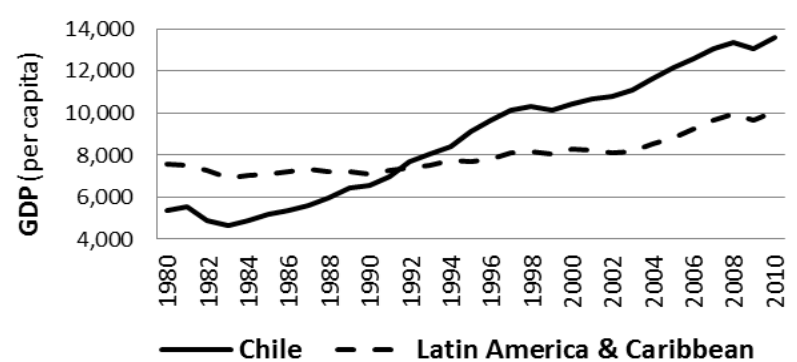

Source: data from World Bank

Fig. 1. Per capita GDP (constant US\$2005) of Chile and LAC. 1980 - 2010.

Consequently, in 2005 the National Innovation Council (NIC) was created to define an innovation strategy that would lead competitiveness improvement because Chile showed and still shows low value-added exports as a result of the traditional low R\&D investment and other innovation deficits To finance this strategy, a royalty to the extraction of copper, the main industry in Chile, was applied along with a tax credit law launched to promote private R\&D investments [34], [39], [40], [1].

Despite the remarkable progress achieved by all these economic and institutional reforms, the national economy has been losing dynamism in the last decade. Some specialists insist in the relevance of those policies that based on a traditional approach emphasize investments in tangibles assets, considering technology and knowledge as exogenous factors that can be obtained elsewhere in the world, keeping the role of the State reduced to solve market failures and to promote entrepreneur activities [10]. However, these policies seem not to be sufficient to support sustainable growth in the future, an aspect reflected in the poor long-run trends of the Chilean economy, as well as in the fall of total factor productivity [40], [1]. This fact is also confirmed by the latest competitiveness report [41], where innovation factors along with other social and economic elements and infrastructures are underlined as main limits for the progress of this country.

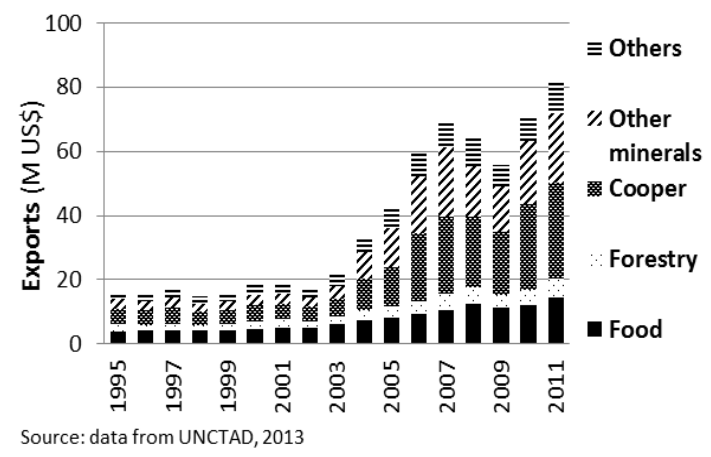

Fig. 2. Exports of Chile by products. $1995-2011$.

To understand this trajectory and the potential future advance of the country, it is important to be aware that historically Chile has been characterized by a strong presence of NR-industries, reason why it is considered as a NR-specialized economy [42], [40]. Both renewable and nonrenewable resources are present, having the sectors of mining, foods (agriculture and fishery) and forestry, a special relevance and orientation toward foreign markets as show the following Fig. 2. The NR exports represent more than $80 \%$ of total exports, corresponding to mining more than $60 \%$ of them, while renewable resources reached around $25 \%$.

\section{EMPIRICAL ANALYSIS: METHODOLOGY AND SOURCES OF INFORMATION}

The first step of this analysis is to identify those elements that are determinants of technical efficiency improvements and significant for catching up processes. This is especially relevant for the possibilities of middle-income countries (MIC), a reason that justifies the election of Chile as target economy in this study. To answer the research question about the key dimensions of the Chilean catching up, an approach based on the Knowledge economy is followed. The results will allow us to detect the fields in which still policies and strategies must focus to improve growth in the long run, and to avoid the NR curse and MIC trap. The orientation of innovation policies, taking into account the NR specialization and built over national system of innovation and Knowledge economy (KE) perspectives, made especially relevant to know the characteristics the gap between Chile and leader countries with similar economic structure and its dynamics. We can expect that our findings provide new clues for policy makers' decisions and for the definition and implementation of more efficient policies. The general assumption is that more efforts should be done to improve local capacities to innovate in NR sectors, creating own technologies and knowledge to reduce the foreign dependence that would improve competitiveness and the added value of the exports.

According to the $\mathrm{KE}$ framework, knowledge and technology are crucial factors to support growth, reason why research in the area devotes great efforts to evaluate and to understand countries' technology gap and then to assist more precisely development strategies. Studies in this tradition have used different methodologies to identify the distance between the leader and countries applying catching-up and benchmarking strategies. It is frequent to measure the gap as the relative distance to leading economies, discussing the reasons explaining the value of this ratio and the need of the adequate policies to converge. Thereby, to detect the determinant factors of the gap, we estimate an applied growth model rooted on the KE framework and the evolutionary theory using a sample of countries identified by cluster technique. This sample is made up by economies characterized for a NR specialized economic structure, high or medium-high income according to the WB classification, and high rates of growth between 1990 and 2008. The solution of the Cluster analysis is one group of countries (called SELECTED) made up by Argentina, Australia, Canada, Chile, Colombia, Kazakhstan, Mexico, Peru, Russia, and South Africa, which is consistent with other studies that analyze NR specialization and successful cases of development [5], [25], [39], [40], [43]-[45].

In a first test we used metafrontier methodology to 
determine and to compare Technical Efficiency (TE) and Technological Gap Ratio (TGR) of SELECTED countries. In order to identify the opportunities derived from improved production efficiency or technological catching up, stochastic metafrontier methodology has become popular in the literature because it identifies the optimal production function of the firms within an industry and the distance of each individual to frontier. This econometric tool can also be applied to evaluate countries as units of analysis [49]. The metafrontier production function [50] is a frontier function that envelops all frontiers of individual regions or groups and permits to deal with the sample technology heterogeneity and to distinguish from technical inefficiency [51], [52].

A second and complementary econometric analysis was conducted to identify the determinant factors of the technology gap in NR-based economies. In order to take into account individual effects, Panel data methodology was employed to estimate the model considering both fixed and random individual effects. The variables were selected according to the literature review and the restrictions of the analytical method. We follow the conventional approach used in other applied growth models, taking labor and capital as the main traditional production factors [53], [54]. Physical investment was used as indicator of capital in a similar way as Stijins and Castellacci [4], [17]. For the analysis of the effect of natural resources, an index of specialization was calculated as the ratio between natural resources exports and total exports. According to evolutionary framework, we also include indicators that reflex innovation capabilities -patents- and absorptive capacity - schooling - [13]. Moreover, the institutions index elaborated according to WB methodology [55] has also been introduced. Finally, the openness and foreign direct investment (inward FDI stock) were selected to proxy international influences. The specification of the GAP model would adopt the following form:

$$
\begin{array}{r}
\mathrm{GDPGAP}_{i t}=\beta 0+\beta 1 \mathrm{~K}_{i t}+\beta 2 \mathrm{~L}_{i t}+\beta 3 \mathrm{NR}_{i t}+\beta 4 \mathrm{Pat}_{i t}+\beta 5 \mathrm{FDIIS}_{i t} \\
+\beta 6 \mathrm{Op}_{i t}+\beta 7 \mathrm{Sch}_{i t}+\beta 8 \mathrm{Ins}_{i t}+\eta_{i}+\gamma_{t}+\varepsilon_{i t}
\end{array}
$$

GDP GAP, K, L, NR, Pat, FDIIS, Op, Sch are expressed as natural logarithms; the subscript it refers to the country $i$ in period $t, \eta i$ and $\gamma t$ represent individual and time effects, respectively; $\varepsilon_{i t}$ is a random error term.

To asses in depth the convergence of each gap component of Chilean economy and the evolution of them, a distance or convergence analysis was driven following $\mathrm{Li}$ and Liu [56], and Salas- $i$-Marti [57]. The distance was calculated according to the next specification:

$$
\mathrm{GAP}_{i t}=\left(\mathrm{Amax}-\mathrm{A}_{i t}\right) / \mathrm{A}_{i t}
$$

where GAP is the gap between the leader and the economy analyzed $i$ in the time $t$; Amax is leader's data; $\mathrm{A}_{i t}$ is data from economy analyzed $(i)$ in the time $t$.

Among SELECTED countries, Australia and Canada show the highest GDP and TE, and the smallest technology gap; but Australia has a more specialized economic structure, thus this country has been considered as leader. In addition, the Chilean data were also compared with USA because this economy is one of the most developed and it is usually used as reference in the gap analysis. However, a complete set of results is also offered in Table II.

Meanwhile, the convergence is estimated as follow:

$$
\mathrm{A}_{i t}=\alpha+\beta_{t}
$$

where A is the GAP between country $i$ and the leader, in the time $\mathrm{t} ; \beta$ is convergence coefficient; $t$ : is time; $\alpha$ is the intersect of the model.

\section{DisCUSSION OF RESUlts}

\section{A. Technical Efficiency and Technical Gap Ratio}

The analysis of TE allows us to know efficiency level of a country to employ its resources -tangible and intangibles- and then management abilities are crucial to understand potential improvements [49], [51], [52]. The results show that Russia, Peru, and South Africa have the lowest TE, with values under $60 \%$ (Fig. 3). This would indicate that these economies can achieve higher performance with the stock of available resources and then their growth opportunities are defined through resources' management. Moreover, although Chile, Colombia, and México also have the opportunity to grow faster by improving their internal processes and use of resources, their gap is narrower and hence they have fewer options via management. On the other hand, Argentina, Canada, Kazakhstan, and Australia are the countries with highest TE, thus growth can be improved from development of new technologies, innovations, or the incorporation of new advances from different areas than the reorganizations of available resources. For the specific case of Chile, the opportunities to improve TE by benchmarking or the incorporation of best practices from the leaders are limited because these have similar TE and the threshold is small; thus it could be more suitable to orient efforts to develop own knowledge, technology and innovations.

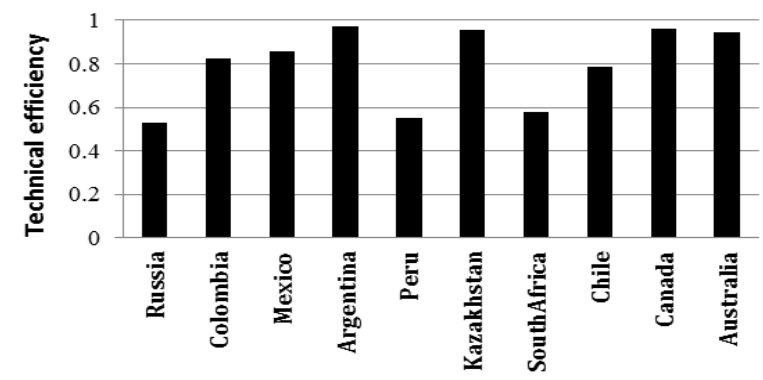

Fig. 3. Technical efficiency taking into account country effects.

Taking into account that the Technological Gap Ratio reflects the available technologies in one country, technological gap is equivalent to $1-$ TGR and this indicates catching up opportunities (Fig. 4). Accordingly, Chile, Canada, and Australia show the lower gap (higher TGR values); however, an important distance still persists, reason why these countries can achieve income improvement using technology available abroad. From the Chilean perspective, both Australia and Canada may serve as leaders for the gap analysis and benchmarking strategies; however, the former 
has a more similar economic structure to Chile and hence a more similar development path to follow. Thus, it can be said that Chile could increase its economic performance both from foreign technologies, using catching up processes beyond NR industries, and improving strategies of resource management. However, these options are not unlimited and local innovations (technological and no-technological) should be encouraged to advance because total convergence doesn't reached by catching up alone and even more, leaders are pressed to innovate in order to expand production and technological frontier to follow their growth path [15], [9].

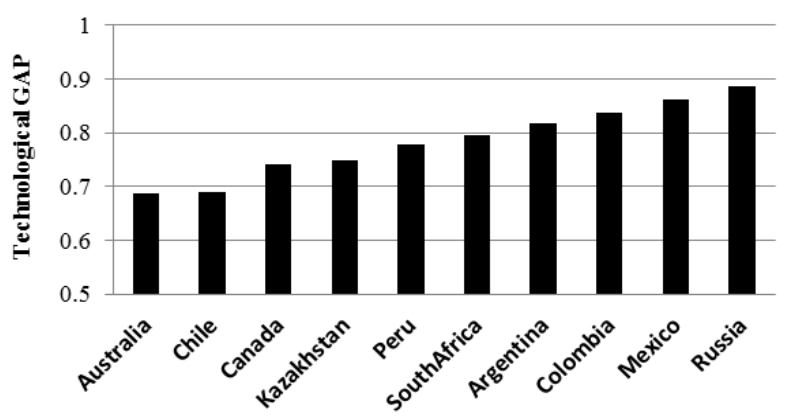

Fig. 4. Technological gap considering country effects.

\section{B. GAP Analysis: GAP Model and Catch up Convergence}

This study focuses on Chile, although policy implications derived from our findings can be generalized to other specialized nations. As the results show, the income gap of economies dominated by NR is explained not only by the traditional production factors but also by other elements postulated by the national system of innovation and KE approaches, having a strong relevance the international dimension (Table I). The results come to indicate that the reduction of the gap in these countries can be done by an increase in capital investment, in accordance with the nature of this economic activity, as well as by the development of innovation capabilities, being also significant trade openness and FDI attraction. This combination of factors is coincident with the assumption that NR can lead development when intangible assets are also incorporated into the growth strategy. In fact, NR specialization positively affect the gap narrowing, a finding that find support in the related literature and evidence that point out that resources may successfully contribute to growth when natural and other traditional factors (capital and labor) are combined with strategic intangible assets, such as human capital, good institutions, and openness policies [28], [46], [31], [32].

The internationalization of these economies is also revealed as a significant factor that affects convergence, in accordance with the importance that in the literature has the international dimension as main source of technology, capital and demand. When the model is estimated without considering the global dimension, the NR exploitation has not impact on the income gap; however, when openness and FDI are incorporated into the model, NR positively affect growth, reducing the gap. This result remarks this aspect for specialized economies, being takeoff inconceivable for a closed NR-producer country. In addition, a more open economy implies that the workforce can move to other productive activities generating the opportunity to develop complementary knowledge intensive goods and services, and even promoting new sectors.

TABLE I: GAP (PER CAPITA) MODEL SELECTED COUNTRIES STATIC

\begin{tabular}{|c|c|c|c|c|c|c|}
\hline \multicolumn{7}{|c|}{ PANEL DATA } \\
\hline & \multicolumn{2}{|c|}{ Model A } & \multicolumn{2}{|c|}{ Model B } & \multicolumn{2}{|c|}{ Model C } \\
\hline & coef & se & coef & se & coef & se \\
\hline Labor & $0.014 * * *$ & 0.003 & $0.018 * * *$ & 0.003 & $0.020 * * *$ & 0.003 \\
\hline NR & -0.003 & 0.002 & $-0.004 * *$ & 0.002 & $-0.003 * *$ & 0.002 \\
\hline Investment & $-0.007 * * *$ & 0.002 & $\begin{array}{r}-0.006 * * \\
*\end{array}$ & 0.001 & $-0.007 * * *$ & 0.001 \\
\hline Patent & $-0.001^{*}$ & 0.000 & $-0.001 *$ & 0.000 & $-0.001 *$ & 0.000 \\
\hline Schooling & -0.005 & 0.005 & -0.004 & 0.005 & -0.004 & 0.005 \\
\hline Openness & & & $-0.003 * *$ & 0.001 & $-0.002 * *$ & 0.001 \\
\hline FDIIS & & & & & $-0.001 * *$ & 0.000 \\
\hline Institution & 0.000 & 0.001 & -0.001 & 0.001 & -0.001 & 0.001 \\
\hline cons & $-0.205^{* * *}$ & 0.052 & $\begin{array}{r}-0.268 * * \\
*\end{array}$ & 0.041 & $-0.299 * * *$ & 0.036 \\
\hline $\begin{array}{l}\text { Hausman test } \\
\text { (Chi-Sq) }\end{array}$ & 45.31 & & 63.04 & & 122.36 & \\
\hline Num. of obs. & 128 & & 128 & & 128 & \\
\hline $\begin{array}{l}\text { R-sq: within } \\
\text { R-sq: }\end{array}$ & 0.5196 & & 0.5547 & & 0.588 & \\
\hline between & 0.0490 & & 0.0648 & & 0.0496 & \\
\hline R-sq: overall & 0.0590 & & 0.0740 & & 0.0580 & \\
\hline
\end{tabular}

The positive relationship between labor and the GDP gap can be explained attending to the fact that NR activities are nowadays capital and scale economies intensive, requiring less amount of labor to increase or maintain the production level [37], [58]. Thus, low-skill workforce or with limited education can be qualified increasing the level of human capital and then be employed in activities related to NR but being more knowledge-intensive, such as the creation of new technologies or knowledge services. In this regard, Manzano [31] argues that for upgrading their productive structure, these economies need better human capital, along with R\&D infrastructure and appropriate institutions, highlighting the importance of skilled workers to face more complex activities in order to add value to exports by creating and incorporating innovations.

The illustration of the convergence analysis shows the successful path of Chile closing the income gap with leaders (Australia, Canada and USA), but its per capita GDP is still about half of the most advanced countries (Fig. 5). Several authors [1], [34], [37], [59] have noted that Chile has achieved a high economic standard in recent decades, with a faster growth in the $90 \mathrm{~s}$, but this progress has not yet been sufficient to complete the gap.

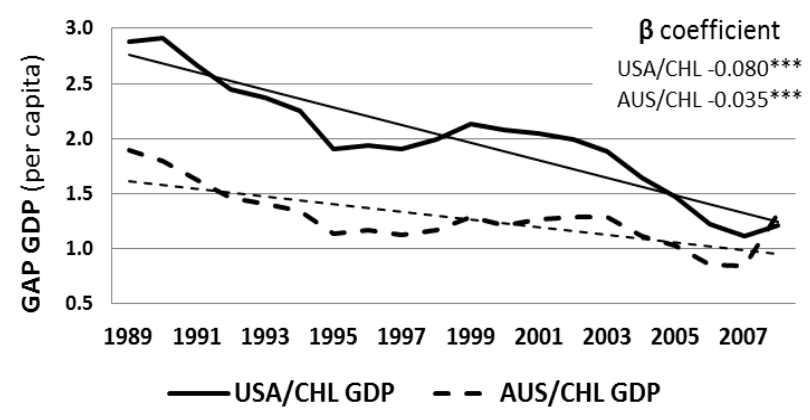

Fig. 5. GAP of GDP between Chile and Australia and USA.

Some of the causes for this convergence are found among 
the government's reforms and the policies implemented decades ago, oriented to opening the country and attracting FDI as a source of capital and technology [1], [34], [36], [58], [60]. However, if we analyze different determinant factors of the gap reduction, important differences arise because Chilean policies have been more oriented to opening and catching up than to building local capabilities (Table II).

In general, differences in convergence with Australia, USA and Canada are slight and can be explained by the diversity of industrial structures and growth strategies. The empirical results show a robust convergence in schooling, scientific articles and infrastructure, confirming the effort carried out for the government to improve productive infrastructures and facilitating the population access to education, at least to primary and secondary levels. Nevertheless, several authors based on international evaluations of the education system indicate that quality is still deficient, and this represents one of most relevant bottlenecks to cross the development threshold.

TABLE II: CONVERGENCE COEFFICIENTS BETWEEN CHILE AND AUSTRALIA, USA, AND INTRAGROUP LEADER

\begin{tabular}{|c|c|c|c|c|}
\hline \multirow[b]{3}{*}{ GDP (per capita) } & \multirow{2}{*}{$\beta$ (AUS) } & \multirow{2}{*}{$\beta$ (USA) } & \multicolumn{2}{|c|}{ Intragroup Leader } \\
\hline & & & Country & $\beta$ (leader) \\
\hline & $-0.035 * * *$ & $-0.080 * * *$ & CAN & $-0.053 * * *$ \\
\hline Investment & $0.010^{* *}$ & 0.0000 & AUS & $0.010^{* *}$ \\
\hline Patent & 0.919 & -9.645 & CAN & -2.372 \\
\hline Schooling & $-0.014 * * *$ & $-0.013 * * *$ & AUS & $-0.014 * * *$ \\
\hline Openness & $-0.006^{* *}$ & -0.002 & CAN & -0.008 \\
\hline FDIIS & $0.000 * * *$ & $0.008 * *$ & CHL & --- \\
\hline Institutions & -0.002 & $-0.011 * * *$ & CAN & $-0.006 * * *$ \\
\hline Science articles & $-0.209 * * *$ & $-0.346 * * *$ & CAN & $-0.360 * * *$ \\
\hline Royalties & $-0.105 * * *$ & -0.008 & CAN & $-0.161 * * *$ \\
\hline GINI & $-0.019 * * *$ & 0.003 & CAN & $0.002 * *$ \\
\hline R\&D & -0.008 & -0.017 & CAN & $0.037 * * *$ \\
\hline Infrastructure. & $-0.075 * * *$ & $-0.083 * * *$ & $\mathrm{KAZ}$ & $-0.044 * * *$ \\
\hline
\end{tabular}

As the NR industries are capital-intensive and require important investments in physical assets, a gap reduction in this production factor is determinant to exploit these endowments. Despite the fact that investment gap has increased during the entire period, Chile has narrowed it in the nineties, this confirming the successful policies applied to promote investments in NR sectors and related services during the last decade of XXI century. This is the result of external inflows of capital through FDI and other foreign investments, mainly as a consequence of public service privatizations and the reinvestment of NR revenue [1], [34], [37], [58]. However, in an extended analysis from 1996 to 2008 , signs of broadening the gap are found at the end of the period although the gap values are around zero.

Taking into account the strategic relevance of physical investment as a way to improve the innovation capability, because some innovation activities require high-cost physical facilities such as scientific infrastructures [9], [61], it is interesting to pay more attention to this variable in the analysis of the causes of the reduction in Chile's attractiveness as a destination for investors. In this sense, related explanations point out that the causes are the raise of labor costs, environmental policies and the perception of higher risks, which could be offset if Chile makes more efforts on other factors of production, as it is proposed by the KE.
As already said, other assets along with physical investment are required to exploit successfully NR such as knowledge and technology [9], [25], [43], [46], [48]. The reason is that countries can improve the production of more value added products and services, to create new ones, or to reduce the costs through innovation, and the NR industries are not an exception.

In this sense, both technology capabilities and absorb capacities are fundamental to developing countries, such as Chile, for catching up and for the development of new knowledge in order to improve the performance of traditional sectors [9], [11], [17], [61]. Therefore, now we move to focus the analysis of patents, as a proxy of innovation capability, while schooling is taken as an indicator of absorption capacity. Chile does not show a reduction in the gap of patents, and this can be seen as a serious barrier for development. In fact, there is evidence in the literature on the weakness that Chile presents in terms of innovation capability or innovation shortfall, regarding R\&D investment level, human capital, and scientific facilities [1], [39], [40], [58], [62]. On the other hand, the indicator of schooling reveals a reduction of this gap in two-thirds regarding the existing in the late eighties, reflecting the advance of absorption capabilities; this is likely the consequence of national policies and the largest education expenditures in the country during recent decades. Nonetheless, there is still the need to improve quality [34] to impact positively on the innovation performance, since innovation and human capital is strongly related.

The important structural reforms established by Chilean governments in the seventies and eighties were orient to improve the macroeconomic behavior, the control of inflation, and to promote international trade and foreign capital inflows and technology [63]. The opening process turned Chile into one of the leaders of international trade, showing a higher openness level than NR leaders (i.e. Canada or Australia), and even leading economies around the World. Inward FDI has converted Chile in one of the most attractive countries to invest in the world, and not only in NR industries but also in service and infrastructures [1], [34], [60]. Scholars agree on the crucial role that the international dimension acquired in the development path of the country, being considered one of the growth engines that has been possible thanks to the economic and social stability, to the suitable incentives to foreign investments and to the production of tradable goods [34], [37]. Thus, this is a key aspect to explain the Chilean economic success that has also been supported by policies that have taken advantage of catching up possibilities.

Since capital and technology are not enough to achieve a permanent successful result of NR exploitation, due to the problems of deindustrialization, depletion, corruption, and social conflicts, it is grounded in the related literature on NR that institutions are also an essential factor to avoid NR curse and turn it into a blessing [2], [8], [31], [43], [59], [64], [65]. The institution's index of Chile presents a lower value (weaker institutions) than leader, but the difference between Australia and Chile is only around $10 \%$ with a decreasing trend, while with Canada or USA is significant lower. Then, adequate institutions (comparatively to other NR-based 
countries) have also been a determinant factor of Chilean growth [34], [59]. This nation has been successful implementing deep reforms on governance, transparency, and corruption control, without falling into pressures resulting from natural resources windfall, but the indictors still have space to improve. According to García [34], the main weaknesses of Chile are related to democratic governance and income distribution. In addition, Figueroa and Calfucura [59] suggest that environmental policies should be urgently improved in order to avoid depletion and pollution.

Other key component of the social dimension is the income distribution in which Chile also shows a deficit. The gap with the USA and Canada has not been closed and the Gini index is still high, an aspect that can adversely affect growth due to the relation of this variable with the stability and persistence of productivity dynamics in the long run [11]. As Morawetz (1977) pointed out "it is not possible to grow first and redistribute later" [66], because progress is defining the pattern of distribution; indeed, multiples social protests and strikes in productive sectors have occurred in recent years, affecting social harmony and production levels as well.

Following the literature on national innovation systems, there is a wide amount of variables that can be used to its analysis [19], [61]. We took some of them to reflect technological and social aspects. One of them is the production of scientific articles, which shows a clear convergence, but the distance to leaders is still large, being is indicator eight to nine times less than Australia, which is consistent with the low technological capabilities that the patents indicator shows. The combined gap of patents and scientific articles denotes a lack of local capacities for the generation of new knowledge and technologies negatively affecting growth. The statistics on royalties (payments) show convergence, which is an example of catching up phase, but this is not sufficient condition for total convergence since local innovation and R\&D are development pillars of advanced economies when they are near the frontier [15], [9]. Therefore, to reach a higher income level, opening and catching up strategies should be strongly complemented with internal capacities in Chile, fostering education, technological capacity and innovation.

There is also convergence in physical assets, such as infrastructures, a result that is consequence of the successful reforms applied in the past that lead the increase of foreign and local investments in road, telecommunications, ports, airports and other strategic facilities and public services, all of this with effects in international trade of NR and the country's competitiveness [15].

\section{CONCLUSIONS AND POLICY IMPLICATIONS}

The contribution of this paper focuses on the identification of the key determinants of national strategies in developing countries based on NR in order to improve growth in the long run, avoiding NR curse and MIC trap. Main attention is paid to the case of Chile, a developing and NR-based country, which is taken as example to illustrate the development path and to detect the factors that have contributed to reduce the gap.
The findings of this paper confirm that specialized economies can successfully face the potential negative effects and pressures of resource-exploitation by means of strategies that combine traditional economic principles with the KE framework that considers intangible assets as a core part of development. For these economies, openness, inward FDI, institutions, technology, and capital investments are key aspects of the development process that permits the reduction of the income gap. In particular, the promotion of more physical investment, openness, inward FDI, and technology capabilities is crucial for the definition of policy actions, from an integrative approach that combines tangible assets with other factors of the national system of innovation.

The data show that Chilean per capita GDP has converged to NR-specialized leaders, as well as the USA. The same trend shows education and openness dimensions, being Chile a leader in inward FDI among the countries analyzed, a result related to both macro and micro economic reforms implemented since the seventies. Additional factors related to national system of innovation, such as royalties and infrastructures also present convergence with developed economies, confirming that Chile has based its growth mainly on physical assets and foreign technology, along with the development of absorptive capacities. However, there are still some aspects to reinforce the Chilean development strategy such as the improvement of technological capacities, one of the main weaknesses observed in this study. It includes the development of scientific capacities, the increase of R\&D investment and activities, and the reorientation of education to innovation, through long-term policies that attend to the cumulative nature of these dimensions.

In the light of this analysis, the bottlenecks of the Chilean development identified through a knowledge base approach allow us to derive several policy implications. Unlike the past, to conduct the progress toward a sustainable path in Chile, technical efficiency of Chile is close to frontier reason why the opportunities of the implementation of best practices from other countries are scarce and the targets should be technological and social innovations more than management improvement. Moreover, foreign knowledge and technologies flow easily into the country but could emerge new barriers that would affect seriously the economic progress, if complementary measures do not enter into scene. Therefore, the task is to improve innovation, and to place it at the core of development policies, maintaining NR-specialized industries but adding value to exports and diversifying them. In addition, the analysis shows some weaknesses in the social aspects, particularly regarding inequality and institutions, in which governments should pay more attention.

\section{REFERENCES}

[1] E. Pérez, "Income convergence, capability divergence, and the middle income trap: An analysis of the case of Chile," Studies in Comparative International Development, vol. 47, no. 2, pp. 185-207, 2012.

[2] J. Sachs and A. Warner, "The big push, natural resource booms and growth," Journal of Development Economics, vol. 59, no. 1, pp. 43-76, 1999.

[3] J. Sachs and A. Warner, "The curse of natural resources," European Economic Review, vol. 45, no. 4, pp. 827-838, 2001.

[4] J. P. Stijns, "Natural resource abundance and economic growth revisited," Resources Policy, vol. 30, no. 2, pp. 107-130, 2005. 
[5] T. Gylfason and G. Zoega, "Natural resources and economic growth: The role of investment," The World Economy, vol. 29, no. 8, pp. 1091-1115, 2006

[6] A. Rosser, "The political economy of the resource curse: A literature survey," IDS publications working paper, no. 268, 2006

[7] D. Lederman and W. Maloney, Natural Resources Neither. Curse Nor Destiny, The World Bank and Stanford University Press, 2007.

[8] F. V. der Ploeg, "Natural resources: Curse or blessing?" Journal of Economic Literature, vol. 49, no. 2, pp. 366-420, 2011.

[9] B. Verspagen, "Uneven growth between interdependent economies: An evolutionary view on technology gaps," $\mathrm{PhD}$ dissertation, Maastricht University, 1993.

[10] R. Nelson, "Institutions, social technologies, and economic progress. The global network for economics of learning, innovation, and competence building system," GLOBELICS working papers series, no. 3, 2007.

[11] F. Castellacci and I. Álvarez, "Innovation, diffusion and cumulative causation: Changes in the Spanish growth regime, 1960 - 2001," International Review of Applied Economics, vol. 20, no. 2, pp. 223-241, 2006.

[12] J. Fagerberg, and B. Verspagen, "Technology-gaps, innovation-diffusion and transformation: An evolutionary interpretation," Research Policy, vol. 31, no. 8, pp. 1291-1304, 2002.

[13] F. Castellacci, "Evolutionary and new growth theories. Are they converging?” Journal of Economic Surveys, vol. 21, no. 3, pp. 585-627, 2007.

[14] G. Dosi, "Sources, procedures, and microeconomic effects of innovation," Journal of Economic Literature, vol. 26, pp. 1120-1171, 1988.

[15] M. Porter "The competitive advantage of nations," Harvard Business Review, vol. 68, no. 2, pp. 73-93, 1990

[16] B. Verspagen, "A new empirical approach to catching up or falling behind," Structural Change and Economic Dynamics, vol. 2, no. 2, pp 359-380, 1991.

[17] F. Castellacci "Technology clubs, technology gaps and growth trajectories," Structural Change and Economic Dynamics, vol. 19, no. 4, pp. 301-314, 2008.

[18] J. Fagerberg, "Technology and international differences in growth rates," Journal of Economic Literature, vol. 32, no. 3, pp. 1147-1175, 1994.

[19] B. Å. Lundvall, "National innovation systems - analytical concept and development tool," Industry and Innovation, vol. 14, no. 1, pp 95-119, 2007.

[20] J. Fagerberg and M. Srholec, "National innovation systems, capabilities and economic development," Research Policy, vol. 37, no. 9, pp. 1417-1435, 2008.

[21] J. Fagerberg, M. Srholec, and B. Verspagen, "The role of innovation in development," Review of Economics and Institutions, vol. 1, no. 2, pp. 1-29, 2010.

[22] L. Edvinsson, "The intellectual capital of nations," in Handbook of Knowledge Management 1 Knowledge Matters, C. Holsapple, Ed., Springer 2003, pp. 153-164.

[23] J. Dunning, "Location and the multinational enterprise: A neglected factor \& quest," Journal of International Business Studies, vol. 40, no. 1, pp. 5-19, 2009.

[24] M. Abramovitz, "Catching up, forging ahead, and falling behind," Journal of Economic History, vol. 46, no. 2, pp. 385-406, 1986.

[25] S. Ville and O. Wicken, "The dynamics of resource-based economic development: Evidence from Australia and Norway," Industrial and Corporate Change, vol. 22, no. 5, 2013.

[26] B. Griffith, "Middle-income trap," in Frontiers in development policy a Primer on Emerging Issues, R. Nallari, S. Yusuf, B. Griffith and R. Bhattacharya, Eds., Washington: The World Bank, 2011, pp. 39-44.

[27] J. Felipe, A. Abdon, and U. Kumar, "Tracking the middle-income trap: What is it, who is in it, and why?" Levy economics institute working paper, no. 715, 2012.

[28] C. B. Ortega and J. D. Gregorio, "The relative richness of the poor?" Natural Resources, Human Capital, and Economic Growth, World Bank, Latin America and the Caribbean Region, Office of the Chief Economist, 2005

[29] S. Smulders, "Endogenous technical change, natural resources and growth," in Scarcity and Growth in the New Millennium, Resources for the Future, R. Ayres, D. Simpson and M. Toman, Eds., Washington, D.C., 2005

[30] R. N. Stavins, "The problem of the commons: Still unsettled after 100 years," American Economic Review, vol. 101, pp. 81-27, February 2011.

[31] O. Manzano, "El rol de los recursos naturales en el desarrollo de
América Latina," presented at the seminary Políticas económicas para un nuevo pacto social en América Latina, Fundación CIDOB Barcelona, 2006.

[32] M. Iizuka and L. Soete, "Catching up in the 21st century: Globalization, knowledge \& capabilities in Latin America, a case for natural resource based activities," UNU-MERIT working paper series, no. 71, 2011.

[33] INE. (2012). Síntesis de resultados. Censo 2012. [Online]. Available: http://www.ine.cl/cd2002/sintesiscensal.pdf

[34] A. García, "Development in Chile 1990-2005: Lessons from a positive experience," Research paper, UNU-Wider, no. 13, 2006.

[35] World Bank. The World Bank. [Online]. Available: http://www.worldbank.org/, 2013

[36] P. Meller, R. O. Ryan, and A. Solimano, "Growth, equity, and the environment in Chile: Issues and evidence," World Development, vol 24, no. 2, pp. 255-272, 1996

[37] R. Álvarez and R. Fuentes, "Pautas de especialización en una economía de rápido crecimiento: El caso de Chile," El Trimestre Económico, vol. 73, no. 292, pp. 749-781, 2006

[38] V. Corbo, L. Hernández, and F. Parro, "Institutions, economic policies and growth. Lessons from the Chilean experience," Central bank of Chile working papers, no. 317, pp. 1-69, 2005.

[39] W. Maloney and A. R. Clare, "Innovation shortfalls," Review of Development Economics, vol. 11, no. 4, pp. 665-684, 2007.

[40] CNIC, Agenda de Innovación y Competitividad 2010 - 2020 Chile, Chile: Consejo Nacional de Innovación para la Competitividad (CNIC) y Secretaría Ejecutiva, 2010.

[41] WEF, The global competitiveness report 2013-2014, Switzerland: World Economic Forum, 2013

[42] W. Maloney, "Missed opportunities: innovation and resource-based growth in Latin America," in Natural Resources, Neither Curse nor Destiny, D. Lederman and W. F. Maloney, Eds., Stanford Economics and Finance and the World Bank, Washington: Stanford University Press, 2007, pp. 141-182.

[43] D. Ferranti, G. Perry, D. Lederman, and W. Maloney, From Natural Resources to the Knowledge Economy: Trade and Job Quality, World Bank, 2002.

[44] M. A. L. Ledesma, "Accumulation, innovation and catching-up: An extended cumulative growth model," Cambridge Journal of Economics, vol. 26, no. 2, pp. 201-216, 2002

[45] F. Castellacci, "Innovation, diffusion and catching up in the fifth long wave," Futures, vol. 38, no. 7, pp. 841-863, 2006

[46] G. Giménez and J. Sanaú, "Interrelationship among institutional infrastructure, technological innovation and growth, an empirical evidence," Applied Economics, vol. 39, no. 10, pp. 1267-1282, 2007.

[47] K. Smith, "Innovation and growth in resource-based economies," CEDA Growth, no. 58, pp. 50-57, July 2007.

[48] E. Silva and A. Teixeira, "Does structure influence growth? A panel data econometric assessment of "relatively less developed countries 1979-2003," Industrial and Corporate Change, vol. 20, no. 2, pp 457-510, 2011

[49] C. O. Donnell, P. Rao, and G. Battese, "Metafrontier frameworks for the study of firm-level efficiencies and technology ratios," Empirical Economics, vol. 34, no. 2, pp. 231-255, 2008.

[50] G. Battese, P. Rao, and C. O. Donnell, "A metafrontier production function for estimation of technical efficiencies and technology gaps for firms operating under different technologies," Journal of Productivity Analysis, vol. 21, no. 1, pp. 91-103, 2004.

[51] G. Battese and P. Rao, "Technology gap, efficiency, and a stochastic metafrontier function," International Journal of Business and Economics, vol. 1, no. 2, pp. 87-93, 2002.

[52] R. Villano, H. M. Boshrabadi, and E. Fleming, "When is metafrontier analysis appropriate?" An example of varietal differences in pistachio production in Iran," Journal of Agricultural Science and Technology, vol. 12 , no. 4, pp. 379-389, 2010.

[53] P. Romer, "Endogenous technological change," Journal of Political Economy, vol. 98, no. 5, pp. S71-S102, 1990.

[54] P. Aghion and P. Howitt, "A model of growth through creative destruction," Econometrica, vol. 60, no. 2, pp. 323-352, 1992.

[55] D. Kaufmann, A. Kraay, and M. Mastruzzi, "Government matters III: Governance indicators for 1996-2002,” Policy research working papers, vol. 3106, August 2003.

[56] X. Li and X. Liu, "Foreign direct investment and economic growth: An increasingly endogenous relationship," World Development, vol. 33 no. 3, pp. 393-407, 2005

[57] X. S. Martin, Apuntes de Crecimiento Económico, Spain: Antoni Bosch Editor, 2000

[58] M. Arias, M. Atienza, and J. Cademartori, "Large mining enterprises and regional development: between the enclave and cluster," Serie de 
Documentos de Trabajo en Economía UCN WP, January 2012.

[59] E. Figueroa and E. Calfucura, "Sustainable development in a natural resource rich economy: The case of Chile in 1985-2004," Environment, Development and Sustainability, vol. 12, no. 5, pp. 647-667, 2010.

[60] T. Bas and M. Kunc, "National systems of innovations and natural resources clusters: Evidence from copper mining industry patents," European Planning Studies, vol. 17, no. 12, pp. 1861-1879, 2009.

[61] F. Castellacci and J. M. Natera, "The dynamics of national innovation systems: A panel cointegration analysis of the coevolution between innovative capability and absorptive capacity," Research Policy, vol. 43, no. 3, pp. 579-594, 2013

[62] J. M. Benavente, "Determinants of industrial research and innovation: The case of Chile," Thesis at the University of Oxford, 2002.

[63] I. Paunovic, Growth and Reforms in Latin America and The Caribbean in the 1990s, United Nations, Economic Commission for Latin America and the Caribbean, 2000.

[64] J. A. Frankel, "The natural resource curse: A survey," Working paper, Harvard Kennedy School, vol. 10, no. 5, pp. 1-45, 2010.

[65] B. Sæther, A. Isaksen, and A. Karlsen, "Innovation by co-evolution in natural resource industries: The Norwegian experience," Geoforum, vol. 42, no. 3, pp. 373-381, 2011

[66] D. Morawetz, Twenty-Five Years of Economic Development 1950 to 1975, the World Bank, 1977, p. 41.

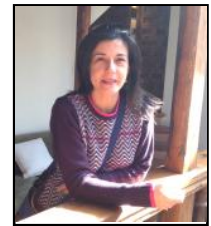

Isabel Alvarez was born in Santa Cruz de Tenerife, Spain, in 1969. She is a Ph.D. in economics, Universidad Autonoma de Madrid, 2003. He is a master on Science, Society and Technology, European Interuniversity Network ESST, École Politechnique Fédérale de Lausanne, in 1995, BA in Economics and Business, Universidad Autonoma de Madrid, in 1992. She is an associate professor at the Economics Department, Universidad Complutense de Madrid. With more than ten years of post-doc experience, her main research interests are on the topic of multinational enterprises, innovation and development. She has published in numerous referred Journals as well as edited books. She has been acting as consultant for several international organizations and she has also been Visiting Scholar at Harvard University and Rutgers University.

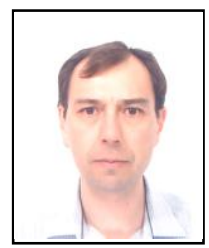

Romilio Labra was born in Curicó, Chile, in 1969. He is a master on business administration, Talca University, Chile, in 2002 and master on Economics and Management of Innovation, Autonomous University of Madrid, Spain, in 2011. He has a BS, Universidad de Concepción, Chile, in 1994. Currently he is a PH.D student at Autonomous University of Madrid, Spain, and works as researcher in the Institute of Agricultural Research of Chile INIA. His scientific interests are innovation, developmen and natural resources. 